\title{
4.2 Загальна характеристика організованих злочинних груп, що вчиняють контрабанду наркотичних засобів у сфері сучасних тенденцій наркобізнесу
}

Постанова проблеми: Наркотизація населення набула масштабів, які загрожують здоров'ю нації, соціальній стабільності і безпеці держави. Вказана проблема в країні характеризується значним збільшенням розповсюдження наркотиків іноземного походження - героїну, кокаїну, амфетаміну та інших, які потрапляють контрабандним шляхом і вливаються в загальний наркобізнес [129, с. 1]. Вказаний процес здійснюється організованими злочинними групами та злочинними організаціями з метою отримання надприбутків і фактично став галуззю кримінального бізнесу.

Закон України «Про обіг в Україні наркотичних засобів, психотропних речовин, їх аналогів і прекурсорів» не визначає поняття наркобізнесу. Бізнес - це підприємницька діяльність, що дає прибуток. Наркобізнес - бізнес, що базується на незаконній торгівлі наркотиків. [131, с. 48].

Г.М. Бірюков, досліджуючи наркобізнес дійшов висновку, що він виступає у вигляді специфічного злочинного промислу, системи заборонених нормами національного i міжнародного права діянь: виробництво або закупівля наркотичних засобів, психотропних речовин та прекурсорів; доставка їх до місця реалізації; збут, продаж їх споживачам [116, с. 17]. На наше переконання контрабанда наркотичних засобів є складовим елементом у технологічному ланцюзі наркобізнесу, який практично пов’язаний з іншими злочинами у сфері незаконного обігу наркотичних засобів.

Е.В. Расюк виділяє наступні елементи наркобізнесу, що вчиняють організовані злочинні групи: великі просторові межі діяльності злочинних груп; застосування способів конспіративності наркодиллерів; значний рівень організації керівництва та ін. [130, с. 440].

I. Смірнова підкреслює, що наркобізнес - це організована складова незаконного обігу наркотичних засобів, психотропних речовин, їх аналогів i прекурсорів, життєзабезпечення якої підтримується завдяки проведенню 
систематичних незаконних операцій із вказаними речовинами організованими групами (злочинними організаціями), що утворює систему для отримання надприбутків та формує велику кількість активних особистостей. Наркобізнес залежно від його географії та ступеня активності характеризується різними видами. Дослідниця зазначає, що принципом поділу виступає у цьому разі територія - від поширення в межах одного або кількох регіонів окремо взятої конкретної країни до такого наркобізнесу, система якого поширюється на території 2-3 країн, а також наркобізнесу, системна злочинна діяльність якого охоплює цілі регіони, континенти. Видами наркобізнесу $\epsilon$ : внутрішньодержавний, який поділяється на локально-активний, регіональний та міжрегіональний; міжнародний, який поділяється на формально проміжноглобально активний та транскордонний транснаціональний [126, с. 480].

Наркобізнес - це нелегальний бізнес із наркотиками, здійснюваний організованою злочинністю. Це підтверджує дослідження В.Б. Івасенка, який вважає, що наркобізнес - незаконна діяльність, що вчиняються організованими злочинними групами 3 метою отримання високих прибутків в процесі вирощення, виготовлення, пересилання та розповсюдження наркотичних засобів, що в кінцевому результатів підриває економічні основи держави та наносить шкоду здоров’ю населеняю [121, с. 30].

За висновками українських експертів, обіг наркотичних засобів в Україні проводиться за допомогою злочинних груп з використанням міжрегіональних та закордонних зв’язків. Зазначені злочинні групи у своїй діяльності використовують недосконалість вітчизняного законодавства, бездіяльність правоохоронних органів та не перекриті кордони ближнього i дальнього зарубіжжя. У зв’язку з наданням Україні безвізового режиму, організовані злочинні групи легко інтегруються в міжнародну систему наркобізнесу. Для нашого i міжнародного суспільства необхідним $є$ створення спільної правоохоронної системи, яка би ефективно протистояла вітчизняним i міжнародним організованим формам злочинності, яка здійснює діяння пов’язанні з наркобізнесом [129, с. 1]. В результаті дослідження встановлено, що 
наркобізнес тісно пов'язаний з діяльністю великої кількості осіб (організованих груп), що передбачає активну діяльність 3 наркотичними засобами, яка здійснюються в процесі: вирощування (25\%); перероблення (28 \%); перевезення (контрабанда) (34 \%); реалізації споживачам (13\%). Зазначені особи об'єктивно змушені об'єднуватися в злочинні групи з метою досягнення матеріальної вигоди від злочинної діяльності та захисту від викриття.

B.I. Литвиненко дійшов висновку, що велику небезпеку для держави становить діяльність організованих злочинних груп, яка полягає не в кількості вчинених злочинів, а в об'єднанні злочинних груп у злочинні організації, котрі посягають на органи управління та влади, заражають їх корумпованістю, впливають на стан суспільства, їх зростаючі масштаби негативно позначаються на економічному процесі розвитку держави, демократизації і суспільного життя країни $[125$, с. 5$]$.

Форми організованої злочинної діяльності постійно розвиваються, змінюються іiі кількісні та якісні характеристики, і не лише під однобічним впливом змін соціального середовища, але й у взаємодії з ним. Діяльність організованих злочинних груп та злочинних організацій характеризує активне бажання залучати та змінювати загальнодержавні інститути у своїх цілях. У загальній структурі злочинності вона посідає центральне місце і $є$ «верхівкою злочинності». У злочинних групах їх лідери постійно підтримують відповідний мікроклімат із метою постійного вчинення ними конкретних злочинних діянь [123, c. 192].

О.М. Джужа, Я.Ю. Кондратьєв та інші вчені стверджують, що одним 3 актуальних завдань, що постає у теперішній час перед юридичною наукою, $є$ розроблення й здійснення ефективних заходів щодо посилення протидії організованим групам у сфері незаконного обігу наркотиків. В подальшому, відзначають дослідники, масштаби існуючої проблеми настільки зростуть, що зараз вони потребують постійного розроблення правового і методичного забезпечення з протидії наркобізнесу [123, с.30]. 
У світлі наведених вище теоретичних положень, організовану злочинну діяльність у сфері контрабанди наркотичних засобів можна визначити як системну сукупність дій підготовлюваних і вчинених спеціально створеними стійкими, законспірованими й захищеними від викриття злочинними групами, що займаються злочинною діяльністю на постійній основі з метою незаконного збагачення й одержання надприбутку.

Способи, якими найчастіше вчиняють протиправні діяння:

1. Вчинення контрабанди наркотичних засобів транснаціональними організованими злочинними групами. Визначити поняття групи як транснаціональної, що вчиняє контрабанду наркотичних засобів можливо за допомогою змісту статті 3 Конвенції ООН проти транснаціональної організованої злочинності 2000 року із Протоколами, де зазначено, що злочин, пов’язаний із такою діяльністю є тоді, коли даний злочин вчинений у двох i більше державах світу; вчинений в одній державі, але початок підготовки здійснювався в іншій; вчиняються на території держави групою, яка діє на території інших держав; злочин може бути вчинений в одній державі, а наслідки наступили в іншій [122, с. 554-606].

2. Вчинення контрабанди наркотичних засобів етнічними організованими злочинними групами. За даними правоохоронних органів України у 2015- 2020 pp. в Україні було виявлено 32 злочинних груп, які були сформовані на етнічній основі, чисельністю 1,1 тис. осіб, котрі були причетні до всіх видів протиправних діянь у сфері обігу наркотичних засобів. За зазначений період до кримінальної відповідальності було притягнуто 250 особи [120, с. 5].

Особливу небезпеку складають злочинні групи які формуються на релігійній основі (мусульманства). Такі групи мають міжнародні зв’язки i фінансують тероризм [117 с. 11].

3. Вчинення контрабанди наркотичних засобів організованими злочинними групами економічного спрямування. Вчинення контрабанди наркотичних засобів організованими злочинними групами економічного спрямування полягає у використанні злочинцями підприємств 
зовнішньоекономічної діяльності у сфері товарної торгівлі, фармацевтики, медицини, поставок для переробки наркотичної сировини, а також вирощування і переробки власної наркосировини 3 використанням іноземних додаткових компонентів та ін.

Організовані злочинні групи, що вчиняють контрабанду наркотиків, використовують створені приватні підприємства (у тому числі фіктивні) для легалізації доходів від індустрії наркобізнесу, яку варто розглядати як одну 3 ключових умов розширення незаконного обігу наркотичних засобів, а також інтенсивного поширення наркоманії з використання легальних і нелегальних бізнесових структур.

При цьому за оцінками фахівців правоохоронних органів, легалізовані кошти використовуються не тільки для продовження злочинної діяльності й гарантування іiі безпеки, але й вкладаються в найбільш перспективні види економічної діяльності.

Злочинні групи, що вчиняють контрабанду наркотичних засобів, 3 транснаціональними ознаками та етнічною спрямованістю, вирізняються високою згуртованістю, стійкістю, кримінальним досвідом і вмілою конспірацією впродовж тривалого часу. Такі групи вчиняють значну кількість контрабанди тяжких наркотичних засобів, більшість із яких залишається нерозслідуваною, а також, дестабілізуючи стан правопорядку, розширюють масштаби злочинних діянь. Вказані проблеми досконало досліджені професором Д. Никифорчуком [126, с. 680-682].

Аналізуючи практику, яка свідчить про те, що організована злочинність у сфері контрабанди наркотичних засобів виділилася в особливу самостійну форму. Основним причина полягає в тому, що організація злочинних груп як ефективно діючих кримінальних структур виявилася набагато більш вигідною, ніж індивідуальний, розрізнений і роз'єднаний злочинний промисел, пов'язаний 3 незаконними операціями з наркотиками.

Організовані форми злочинності $\epsilon$ складним явищем, своєрідним чинником політичної господарської проблеми в державі. Угрупування 
транснаціонального та етнічного спрямування постійно удосконалюють свою злочинну діяльність, завойовують території різних держав, створюють міжрегіональні та міжнародні наркокартелі. У сьогодні на території нашої країни діють організовані злочинні групи у сфері незаконного обігу наркотиків, які мають тісні зв'язки з окремими державними чиновниками та підприємцями i здійснюють суттєвий контроль над суб'єктами підприємницької діяльності [126, c. 539].

Злочинні групи транснаціонального, економічного i етнічного спрямування у діях яких містяться ознаки контрабанди наркотичних засобів, належать до безпосередніх об’єктів оперативно-слідчої діяльності правоохоронних органів України. Щодо таких груп, за наявності достовірної інформації, отриманої в установленому законом порядку, яка потребує перевірки оперативно-розшуковим шляхом, можуть бути заведені оперативно-розшукові справи, у межах яких здійснюються певні заходи ОРД, а також використовуються необхідні оперативні й оперативно-технічні засоби $[115$, с. 15 29].

3 метою ефективної протидії контрабанді наркотичних засобів вчиненої в складі групи, необхідно дослідити визначення та розмежування поняття «злочинна група», «організована група», «злочинне угрупування», «злочинне співтовариство» тощо.

Кримінологи досліджують причини і умови створення злочинних груп, розроблення заходів, спрямованих на їх припинення. Фахівців у сфері кримінального права цікавлять питання кримінальної відповідальності за злочини, які вчинила група з ознаками організованості. Практиків оперативнорозшукової діяльності інтересує тактика виявлення і документування злочинних дій, вчинених злочинними групами. У процесуалістів проблемою являється удосконалення тактики слідчих (розшукових) дій при розслідуванні групових злочинів.

У сучасній літературі вже висловлювалася думка про те, що суто кримінально-правовий або кримінологічний аналіз поняття, яке розглядається, 
звужує поняття таких груп. Розуміння такого поняття досягається комплексним дослідженням всіх юридичних наук і надає уявлення про всю сукупну єдність суттєвих ознак саме організованих злочинних груп, особистість їх учасників та їх організовану злочинну діяльність. Водночас, як зазначає Б.С. Воронцов, для визначення ознак злочинної групи необхідно використовувати і соціологічні науки, які дають поняття групового об'єднання [126, с. 53].

За теорією Б.І. Бараненка, системно-комплексний підхід дозволяє розглядати злочинні групи як: соціальні групи, тобто порівняно стійкі групи осіб, що об’єдналися на основі соціальних чи економічних інтересів і створені безпосередні зв'язки між їх членами (зрозуміло, в межах кримінального їх буття); соціально-психологічні утворення, тобто об'єднання людей, які характеризуються своєрідною протиправною поведінкою і діяльністю, а також особливою особистісною психологією, обумовленою фактом належності цих людей до вказаних соціальних груп; суб'єкти групової організованої злочинної діяльності, яка створює поєднання зусиль декількох осіб для успішної реалізації загальної злочинної мети, а також найбільш раціональні спільні дії (включаючи самі засоби, способи дій та їх результати) на основі визначених правил та процедур [115, с. 16].

Запропонований підхід призводить до об’єктивного розуміння організованих злочинних груп як суб'єктів групової організованої злочинної діяльності. Саме ці групи в сукупності зі злочинною діяльністю, яку вони здійснюють, визначають матеріальний зміст явища більш високого соціального рівня, тобто організованої злочинності, і одночасно виконують роль безпосередніх об'єктів оперативно-розшукового втручання у боротьбі з цією злочинністю. Науковці по різному характеризують поняття організованої злочинної групи:

- як об’єднання декількох осіб із антисуспільними поглядами для реалізації злочинних дій, які є кримінально карними; 
- як неформальне об’єднання осіб на основі вчинення суспільно небезпечних, протиправних діянь, які прагнуть до досягнення загальної мети, організовані певним чином і становлять один суб’єкт діяльності;

- як стійку групу, що складається 3 трьох і більш осіб, яка раніше організувалася для сумісного вчинення одного або декількох злочинів;

- як навмисно організоване злочинне утворення, що охоплює лідера (він же найчастіше являється організатором) і декількох спільників, які перебувають у попередньому зговорі і мають на меті отримання прибутку від злочинів різної;

- група характеризується заздалегідь спланованою і цілеспрямованою злочинною поведінкою й домовленістю про постійну злочинну діяльність;

- стале об’єднання трьох і більше осіб, які зорганізувалися для отримання матеріальної вигоди вчиненням одного або кількох злочинів;

- як стійку групу осіб, які заздалегідь об’єдналися для вчинення одного або кількох злочинів і мають у своєму складі організатора.

Водночас К.О. Чаплинський в процесі вивчення організованих форм злочинності визначив, що організована група складає початкову форму організації та є фундаментом всієї злочинності. Злочинці, які об’єднані в групу, мають високий ступінь криміногенності та психологічної згуртованості довкола лідера. Чим більше група вчиняє злочинів, тим більше збільшується термін їі дії. Розподілення ролей в групі здійснюється в залежності вміння членів виконувати окремі злочинні функції [132, с. 34].

B.I. Литвиненко, Г.М. Бірюков та I.В. Сервецький характеризують організовані форми злочинів як умисно зорганізоване злочинне утворення, що включає лідера (він же найчастіше організатор) і декількох спільників, що перебувають у попередній змові і мають на меті одержання доходів від вчинення злочинів різної чи однієї кримінальної спрямованості, здійснення яких вимагає організаційного й іншого підготовчого забезпечення: планування, технічної оснащеності, розподілу ролей, розробки способів запобігання відповідальності та ін. $[124$, c. 27$]$. 
В.М. Корнієнко і Б.В. Романюк за характером стійкості наводять ознаки видів організованих злочинних груп: до першої групи (проста) вони відносять об'єднання злочинців які вчиняють крадіжки, шахрайства, грабежі, їх чисельність нараховує 3-5 осіб; до другої групи науковці відносять осіб, чисельність яких становить від 5 до 10 членів (структурована) в якій виділяються ієрархічні ознаки. Така злочинна група вчиняє злочини постійно, як правило корисливонасильницькі злочини, між учасниками існує розприділення ролей та наявність головного лідера [126, с. 192-193].

Наступною рисою організованої злочинної групи являється ії стійкість. Група яка вчиняє контрабанду наркотичних засобів буде стійкою за умови якщо вона нараховує стабільну чисельність їі членів і мають єдині наміри щодо вчинення зазначених злочинів.

Така риса організованої злочинної групи як згуртованість визначається шляхом їх поєднання (спаяності) та одностайності у своїх намірах. Для таких ознак характерно віднести міжособистісні внутрішні взаємовідносини між членами групи, визначення загальних норм поведінки, підпорядкування одному лідерові, розприділення ролей в залежності кримінального досвіду, злочинна діяльність завчасно планується і направляється за узгодженням дій [126, с. 683].

Визначення ознаки стабільної організованої злочинної групи проводиться на основі встановлення ii постійної злочинної діяльності. Група являється стабільною, якщо вона вчасно поповнюється новими членами групи, які за об’єктивними чи суб' єктивними причинами вибули.

Так професор А.А. Музика до стійкої організованої злочинної групи відносить трьох і більше осіб, які об'єдналися за попередньою змовою для підготовки та вчинення кримінальних правопорушень. До обов'язкових ознак від відносить наявність домовленості про створення такого організованого об'єднання; наявність домовленості про вчинення злочинів; спільне планування протиправних діянь; визначення ролевих функцій для членів групи; доведення злочинних намірів до всіх учасників злочину [127, с. 94]. 
Б.І. Бараненко визначає організовані злочинні групи в залежності їx розвитку. Так, до першої групи відносить просте об'єднання в склад якого входить декілька членів, які вчиняють злочини за попередньою змовою. Такою групою керує організатор. До другого організованого об'єднання від відносить організоване угруповання, яке складається з об'єднаних двох і більше злочинних груп. Таке об'єднання з часом може перерости в злочинну організацію і мати чітку ієрархічну структуру 3 розподілом ролей та спеціальних ланок забезпечення [126, с. 17].

В окремих наукових дослідження визначається ще один вид організованих злочинних груп - організоване злочинне співтовариство (синдикат, мафія). Зазначене злочинне об'єднання має характерні ознаки, які визначаються великою територіальною діяльністю, наявністю правил прийняття в об'єднання нових членів, застосування засобів покарання для зрадників, встановлення обов'язкових (матеріальних) зобов'язань для постраждавши членів угрупування від правоохоронних органів тощо [126, с. 684].

Саме ці ознаки відносяться до механізму вчинення протиправних діянь, що в кримінальному законі визначаються обов'язкові ознаки організованих злочинних груп, які дають підстави для їх розподілу на види. У той же час на практиці визначення організованих злочинних груп на початковій стадії їх виявлення можливо тільки за допомогою додаткових ознак таких як: проведення злочинних сходок злочинних авторитетів, вчинення розборок між групами, факти викрадення людей, вимагання тощо.

Під час розслідування зазначених кримінальних проваджень виникають суттєві проблеми з визначення видів злочинних груп. У більшості випадків виявляються групи, які вчинили злочин за попередньою змовою (95 \%), дуже рідко без змови взагалі (5 \%). Для встановлення протиправного діяння вчиненого організованою групою в конкретному випадку необхідно зазначати, за якими ознаками злочинна група є організованою. При класифікації злочинних груп учені використовують і різні кваліфікуючі ознаки. Так, А.П. Герасименко, Ю.В. Дамов беруть за основу безпосередній характер діяльності учасників груп, 
характер суб’єктивного зв'язку між членами групи, роль кожного з учасників групи. По-перше, організованість включає структуру групи, форми, тактику діяльності, характер зв’язку між іiі членами тощо (об'єктивна ознака узагальнювальної властивості). По-друге, організована діяльність достатньо чітко оцінюється кримінально-правовими, соціальнопсихологічними, а також оперативно-розшуковими критеріями. Рівень формування злочинної групи визначає ступінь організації діяльності правоохоронних органів, зокрема оперативних підрозділів [127, с. 93].

Виявляючи організовані злочинні групи оперативно-розшуковим шляхом, необхідно зважати на дії їх членів, що мають охоплюватися нормою Кримінального кодексу України передбачених в ч. 3 статті 305 КК України.

У науці кримінального права дотепер існує точка зору, відповідно, зміст основних ознаки кримінального правопорушення, що вчинені групою тлумачиться винятково як співвиконавство.

Проте в деякій навчальній літературі з кримінального права України чітко зазначено, що ця змова може відбутися перед діянням, або на стадії замаху чи до нього [114, с. 203], в іншій - визнається можливість виникнення попередньої домовленості в процесі замаху [113, с. 191].

Досліджуючи правові норми Великобританії, встановлено, що основними джерелами визначення вказаної злочинної діяльності є статті кримінального права (парламентське законодавство) i судові прецеденти. Англійський кримінальний закон не передбачає поняття організованої злочинної групи, але використовує термін «змова». Пункт $2 \S 3$ Закону про кримінальне право передбачає, що особа, винна у змові з метою вчинення вбивства, карається довічним тюремним ув’язненням [ 118, с. 581].

Незважаючи на обов’язкові ознаки групи, зазначені у законі, існують інші, на які немає прямого посилання. Ці ознаки можна розглядати як додаткові. На основі вивчення кримінальних проваджень про злочинну діяльність організованих злочинних груп, які вчиняли контрабанду наркотиків, були виявлені такі додаткові ознаки: чітка ієрархія та наявність лідера; чіткий 
розподіл ролей і закріплення функцій у групі. В організованій групі ролі чітко розподіляються, одні члени беруть участь у підготовці протиправних діянь, інші - безпосередньо перетинають кордон 3 наркотиками, треті - забезпечують перевезення і збут наркотиків. Кожний знає свої обов'язки, тому група функціонує злагоджено й організовано; планований характер злочинної діяльності. Практично усі групи вчиняють контрабанду на основі заздалегідь розробленого плану. Тому тривалість функціонування таких груп неможлива без планування їх специфічної діяльності. 